\title{
Polymorphism of Acid and Neutral $\alpha$-Glucosidases in Banana Pulp: Changes in Apparent pIs and Affinity to Con A of the Enzymes during Ripening
}

\author{
Yôtarô Konishi, * Sachiko Krtazato, Ryôko Asano \\ and Nobuji NAKaTANI \\ Department of Food and Nutrition, Faculty of Science of Living, Osaka City University, \\ 3-3-138 Sugimoto, Sumiyoshi-ku, Osaka 558, Japan \\ Received October 29, 1990
}

\begin{abstract}
We observed the presence of acid and neutral $\alpha$-glucosidases with optimum $\mathrm{pHs}$ of 4.5 and 6.5, respectively, and their multiple forms in banana pulp. By chromatofocusing analysis, each $\alpha$-glucosidase from preclimacteric bananas was found to be of $\mathrm{pI}>7.4$, which disappeared upon ripening, although another form with pI 5 as a major component appeared instead. It is unknown whether this phenomenon is due to protein de novo synthesis and/or post-translational modifications of the enzyme. A large amount of acid $\alpha$-glucosidase from preclimacteric bananas was shown to be a glycoprotein that bound to a Con A-Sepharose column. While this type of enzyme decreased during ripening, it remained a possibility that sugar components of the enzyme might be processed during ripening. The neutral $\alpha$-glucosidase had no affinity to the column through ripening. These results provide preliminary information on the mechanism of appearance of $\alpha$-glucosidase multiforms as well as on a useful strategy for purification of acid and neutral $\alpha$-glucosidases from banana pulp at various stages of ripening.
\end{abstract}

Starch breakdown is one of the most noticeable changes in ripening of climacteric fruits. In bananas, the starch content decreases from $15-20 \%$ in the preclimacteric phase to less than $1 \%$ in the postclimacteric phase. ${ }^{1,2)}$ Exogeneous ethylene shortens the preclimacteric period.

In most nonphotosynthetic starch storage tissues like banana pulp, $\alpha$-amylase has been considered to be involved in the initiation of starch degradation to produce malto-oligosaccharides, since this enzyme is able to bind to starch granules. ${ }^{3,4)}$ Afterwards, the maltooligosaccharides are degraded via hydrolytic and/or phosphorolytic pathways. ${ }^{5)}$ There are many reports showing the close relationships between starch degradation in bananas and the increased activities of starch hydrolytic enzymes including $\alpha$ - and $\beta$-amylases, ${ }^{6-9)}$ debranching enzyme, ${ }^{9)}$ and $\alpha$-glucosidase. ${ }^{9)}$ Phosphorylase activity, however, has been shown to decrease as starch degradation proceeds. ${ }^{6,7,10)}$ Unfortunately, the exact mechanism or the regulation of starch degradation in bananas has not been fully explained, because of lack of characterization of the related enzymes or the concentration of intermediates in banana tissues. In addition, heterogeneity of the enzymes of starch metabolism makes the above point complex. ${ }^{4)}$

$\alpha$-Glucosidase [EC 3.2.1.20] in banana tissues has attracted little attention. Garcia and Lajolo $^{9)}$ observed an increased activity of $\alpha$-glucosidase at the climacteric phase and heterogeneity of this enzyme by activity staining after polyacrylamide gel electrophoresis. Their report led us to attempt to purify $\alpha$-glucosidase from banana pulp tissues. We have reported that there existed acid and neutral $\alpha$-glucosidases and their polymorphism. ${ }^{11)}$ In this paper, we report the changes in acid and neutral forms of $\alpha$-glucosidases on

* To whom correspondence should be addressed. 
chromatofocusing or a Con A affinity column during ripening of banans.

\section{Materials and Methods}

1) Reagents. 4-Methylumbelliferyl- $\alpha$-D-glucoside ( $4 \mathrm{MU} \alpha \mathrm{G}$ ) was a product of Sigma. Polybuffer 74, Polybuffer exchanger (PBE) 94, CM-Sepharose CL-6B, and Con A-Sepharose were obtained from Pharmacia LKB Biotechnology. Polyvinylpyrrolidone (PVP) 25 was from Nacalai Tesque, Inc., Kyoto.

2) Banana samples. Green bananas (Musa sapientum L. CV. Giant Cavendishii) before and after treating with ethylene (approx. $1000 \mathrm{ppm}$ for $24 \mathrm{hr}$ at $15^{\circ} \mathrm{C}$ ) were obtained from the Osaka Banana Center. They were stored at $22^{\circ} \mathrm{C}$ until use. Banana pulp $(20 \mathrm{~g})$, after slicing for green bananas, was homogenized with $30 \mathrm{ml}$ of $0.1 \mathrm{M}$ glycylglycine buffer ( $\mathrm{pH}$ 7.0) containing 1\% PVP (to bind polyphenols ${ }^{12}$ ), $20 \mathrm{~mm}$ cysteine (to prevent browning), and $0.1 \mathrm{~mm}$ EDTA using a Potter-Elvehjem teflon homogenizer. After centrifugation $(20,000 \times g, 30 \mathrm{~min})$, a supernatant (crude extract) was obtained. Enzymes in the crude extract were precipitated by adding polyethylene glycol (PEG) $6000(0.2 \mathrm{~g} / \mathrm{ml})$ or by ammonium sulfate $(60 \%$ saturation).

3) Enzyme assay, $\alpha$-Glucosidase activity was measured fluorimetrically using $4 \mathrm{MU} \alpha \mathrm{G}$ as a substrate. ${ }^{13)}$ The reaction mixture $(1 \mathrm{ml})$ contained $0.1 \mathrm{ml}$ of enzyme, $0.6 \mathrm{ml}$ of $0.1 \mathrm{M}$ citrate-phosphate buffer ( $\mathrm{pH} 4.5$ or 6.5$)$, and $0.3 \mathrm{ml}$ of $0.33 \mathrm{~mm} 4 \mathrm{MU} \alpha \mathrm{G}$. The reaction was done at $37^{\circ} \mathrm{C}$ for $30 \mathrm{~min}$ and stopped by adding $3 \mathrm{ml}$ of $0.5 \mathrm{M}$ glycine- $\mathrm{NaOH}$ buffer ( $\mathrm{pH}$ 10.5). Fluorescence was measured with a Shimadzu RF-540 spectrophotometer at an emission wavelength of $450 \mathrm{~nm}$ and an excitation wavelength of $366 \mathrm{~nm}$. One unit was defined as the amount of enzyme producing $1 \mu \mathrm{mol} 4 \mathrm{MU} / \mathrm{min}$.

4) Measurements of $\mathrm{CO}_{2}$. The banana sample was placed for 1 or $2 \mathrm{hr}$ in a container $(V=161)$. The $\mathrm{CO}_{2}$ production was measured using a Gastec $\mathrm{CO}_{2}$ sensor (Gastec Co., Ltd., Kanazawa).

5) CM-Sepharose CL-6B column chromatography. Material precipitated by $60 \%$ saturation. with ammonium sulfate was dissolved in $10 \mathrm{~mm}$ sodium acetate buffer $(\mathrm{pH}$ 6.2 ), dialyzed against the same buffer, and put on a CM-Sepharose CL-6B column $(1 \times 16 \mathrm{~cm})$. After the column was washed with the same buffer, it was eluted with a linear gradient ( $10-400 \mathrm{~mm}$ sodium acetate, $\mathrm{pH} 6.2)$.

6) Chromatofocusing. The precipitate obtained by adding PEG to the crude extracts was dissolved in $25 \mathrm{~mm}$ imidazole- $\mathrm{HCl}$ buffer ( $\mathrm{pH}$ 7.4). The sample was put on a column packed with $\mathrm{PBE} 94(0.7 \times 5.2 \mathrm{~cm})$ preequilibrated with the same buffer. Chromatofocusing was done by elution with $50 \mathrm{ml}$ of the 9-fold diluted polybuffer 74 , according to the instructions from Pharmacia LKB Biotechnology.

7) Con A-Sepharose column chromatography. The pellet from PEG was dialyzed against phosphate buffer $(50 \mathrm{~mm}$, $\mathrm{pH}$ 6.5) containing $2 \mathrm{mM}$ dithiothreitol and $0.1 \mathrm{M} \mathrm{NaCl}$, then put on a Con A-Sepharose column $(0.7 \times 5.2 \mathrm{~cm})$ preequilibrated with the same buffer. After the column was washed with $50 \mathrm{ml}$ of the buffer, the buffer containing methyl $\alpha$-D-glucopyranoside ( $15 \mathrm{~mm}$ ) was applied.

\section{Results}

\section{1) Evidence for the presence of acid and neutral} $\alpha$-glucosidases in banana pulp

Figure 1 shows $\mathrm{pH}$-activity and $\mathrm{pH}$-stability curves of $\alpha$-glucosidase using crude extracts of ripe yellow banana pulp, giving two optimum peaks, pH 4.5 and pH 6.5 (Fig. 1A); the former is defined as acid $\alpha$-glucosidase and the latter as neutral $\alpha$-glucosidase. Acid $\alpha$-glucosidase was completely stable at $\mathrm{pH} 3-8$ for $20 \mathrm{hr}$ at $4^{\circ} \mathrm{C}$, while neutral $\alpha$-glucosidase was labile at acidic $\mathrm{pH}$ but stable at neutral pH (Fig. 1B). Figure 2 shows residual enzymic activities measured at $\mathrm{pHs}$ of 4.5 and 6.5 upon heating

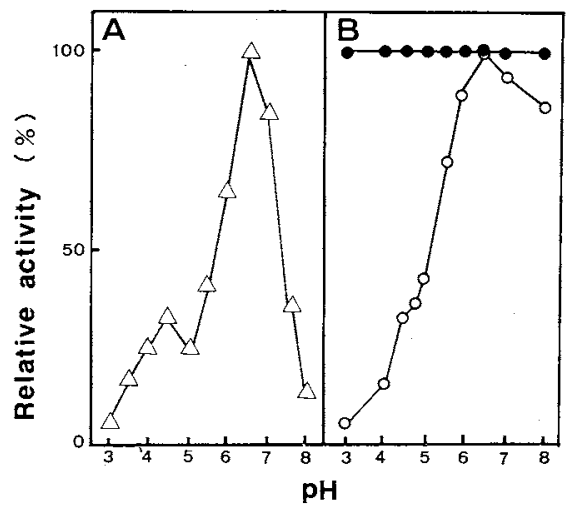

Fig. 1. $\mathrm{pH}-$ Activity (A) and $\mathrm{pH}-$ Stability (B) Curves of $\alpha$-Glucosidases from a Ripe Yellow Banana.

(A): $\alpha$-Glucosidase activity at various $\mathrm{pHs}$ were measured with crude extracts of banana pulp as an enzyme source. The $100 \%$ value is $1.9 \mathrm{mU} / \mathrm{ml}$ at $\mathrm{pH} 6.5$. (B): The crude extract was left for $20 \mathrm{~h}$ at $4 \mathrm{C}$ at the indicated $\mathrm{pHs}$, followed by measurement of enzyme activities at $\mathrm{pH} 4.5$ (O) and pH $6.5(\mathrm{O})$. The $100 \%$ values of acid and neutral $\alpha$-glucosidases are $0.69 \mathrm{mU} / \mathrm{ml}$ and $2.60 \mathrm{mU} / \mathrm{ml}$, respectively. 
the crude extracts at various temperatures $\left(37-80^{\circ} \mathrm{C}\right)$ for $5 \mathrm{~min}$. The temperature which reduced $50 \%$ of enzyme activities was found to be $52^{\circ} \mathrm{C}$ for acid $\alpha$-glucosidase and $72^{\circ} \mathrm{C}$ for neutral $\alpha$-glucosidase, suggesting these enzymes are different proteins. Acid and neutral $\alpha$-glucosidases were in part retained on a CM-Sepharose CL-6B column at $\mathrm{pH} 6.2$ and were eluted with $0.33 \mathrm{M}$ and $0.13 \mathrm{M}$ sodium

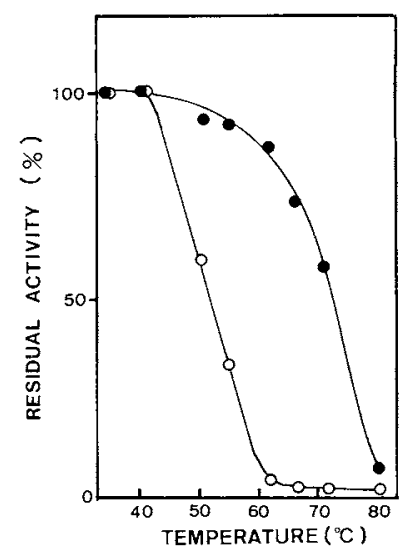

Fig. 2. Heat Stability of $\alpha$-Glucosidases from a Ripe Yellow Banana.

The crude extracts was used as a enzyme source and heated at various temperatures for $5 \mathrm{~min}$, followed by measurement of enzyme activities at $\mathrm{pH} 4.5(\mathbf{O})$ and $\mathrm{pH} 6.5(0)$. The $100 \%$ value is obtained from the non-heated sample and is $0.10 \mathrm{mU} / \mathrm{ml}$ at $\mathrm{pH} 4.5$ or $0.72 \mathrm{mU} / \mathrm{ml}$ at $\mathrm{pH} 6.5$. acetate buffer, respectively (Fig. 3). These results demonstrate the presence of acid and neutral $\alpha$-glucosidases in banana pulp.

\section{2) Changes in activities of $\alpha$-glucosidases during ripening of bananas}

Figure 4 shows the changes in peel color index, the rate of $\mathrm{CO}_{2}$ production, and activities of acid and neutral $\alpha$-glucosidases of bananas before and after the ethylene treatment. By measuring of the rate of $\mathrm{CO}_{2}$ production, the climacteric peak of the sample used in this experiment was reached $24 \mathrm{hr}$ after the end of the ethylene treatment. Activities of acid and neutral $\alpha$-glucosidases of the sample without ethylene treatment were very low, and they increased by 2 or 3 -fold at the climacteric phase, showing complex changes thereafter.

\section{3) Changes in apparent pIs of $\alpha$-glucosidases during ripening of bananas}

We sometimes found that the amount of acid or neutral $\alpha$-glucosidase retained on a CMSepharose column (see Fig. 3) was variable among samples purchased, suggesting that apparent pIs of $\alpha$-glucosidases are changeable during ripening. We therefore examined this by chromatofocusing (Fig. 5). From the ethylene-untreated green banana, both acid

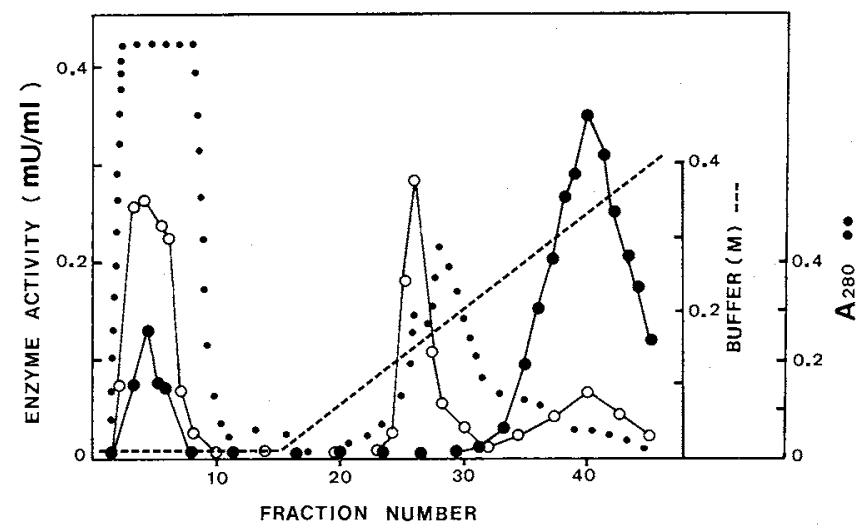

Fig. 3. Chromatogram of Banana $\alpha$-Glucosidases on a CM-Sepharose CL-6B Column.

The precipitate with ammonium sulfate $(60 \%$ saturation) from the crude extracts ( $40 \mathrm{~g}$ banana equivalent) was put on a CM-Sepharose CL-6B column preequilibrated with sodium acetate buffer (10 mM, pH 6.2). After the column was washed with the same buffer, a linear gradient (10 $400 \mathrm{~mm}$ sodium acetate, $\mathrm{pH} 6.2$ ) was developed at a flow rate of $15 \mathrm{ml} / \mathrm{hr}$ and collected $3.8 \mathrm{mI}$ per tube. $O$, acid $\alpha$-glucosidase; $O$, neutral $\alpha$-glucosidase. 


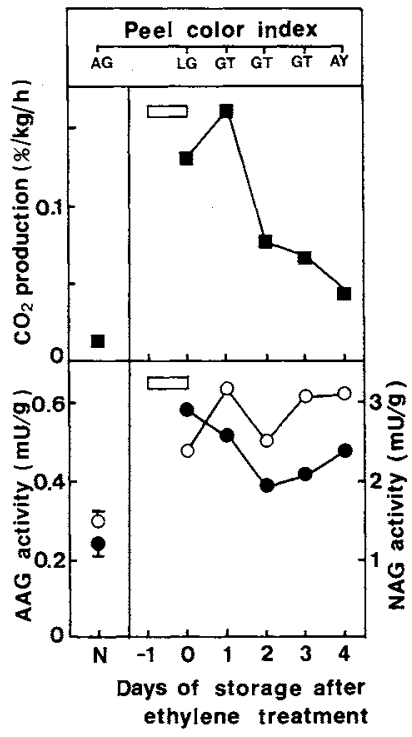

Fig. 4. Changes in Peel Color Index, $\mathrm{CO}_{2}$ Production, and Activities of Acid and Neutral $\alpha$-Glucosidases of Bananas before and after Ethylene Treatment.

Bar indicates duration of ethylene treatment (approx. $1,000 \mathrm{ppm}, 24 \mathrm{hr}$ ). AAG, acid $\alpha$-glucosidase (O); NAG, neutral $\alpha$-glucosidase $(O)$; AG, all green; LG, light green; GT, green tip; AY, all yellow; $N$, samples not treated with ethylene.

and neutral $\alpha$-glucosidases were shown to have pI $>7.4$ (Fig. 5A). Similar results were obtained from a green banana $24 \mathrm{hr}$ after the end of the ethylene treatment ( 0 day of storage) (Fig. 5B) and from the 1 st day of storage (data not shown). From a ripe yellow banana (the 4th day of storage), however, the neutral $\alpha$ glucosidase with $\mathrm{pI}>7.4$ disappered and enzyme with pI 5 appeared instead. Acid $\alpha$-glucosidase showed near pI 5 as major and other various pIs from the same sample (Fig. 5 C).

4) Changes in affinity of $\alpha$-glucosidases for the Con A-Sepharose column during ripening of bananas

Figure 6 shows Con A affinity chromatograms of $\alpha$-glucosidases from bananas with different stages of ripening. From the ethyleneuntreated banana (Fig. 6A) and the sample of the 0 day of storage after the ethylene treatment (Fig. 6B), a large amount of acid $\alpha$-glucosidase

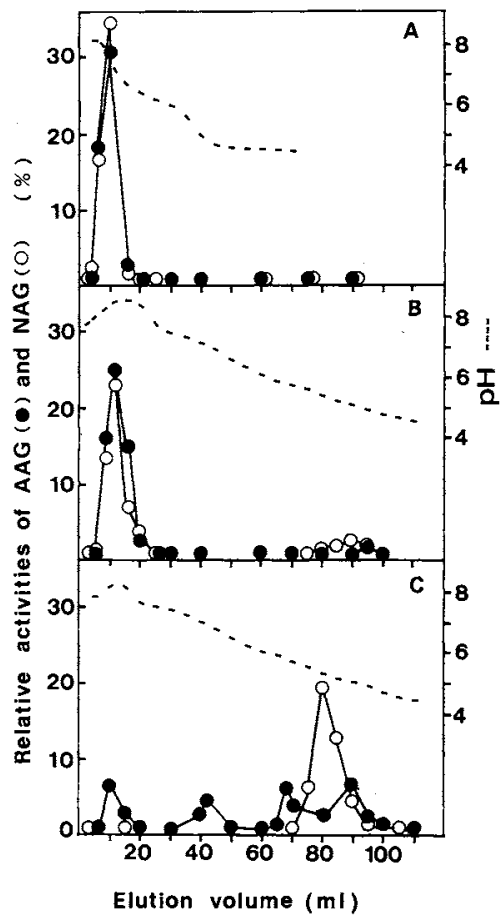

Fig. 5. Chromatofocusing of Banana $\alpha$-Glucosidases.

The active fraction was obtained by $20 \%$ PEG precipitation from the crude extracts, dissolved in $25 \mathrm{~mm}$ imidazole- $\mathrm{HCl}$ buffer ( $\mathrm{pH} 7.4$ ) and put on a column packed with Pharmacia PBE 94 equilibrated with the same buffer. The $\mathrm{pH}$ gradient was developed by applying the 9 -fold diluted Polybuffer 74 to the column. The ordinate scale shows the relative activity ( $\%$ of total) of the enzyme measured at $\mathrm{pH} 4.5$ (acid $\alpha$-glucosidase, AAG) or at $\mathrm{pH}$ 6.5 (neutral $\alpha$-glucosidase, NAG). (A): A green banana without ethylene treatment. (B): A light green banana 0 day after the end of the ethylene treatment. (C): A ripe yellow banana 4 days after the end of the ethylene treatment.

was shown to be glycoprotein that bound to a Con A column. However, when ripened (Fig. $6 \mathrm{C})$, the amount of the glycoproteinous enzyme decreased. On the other hand, neutral $\alpha$ glucosidase from preclimacteric and ripe bananas had no affinity for the Con A column. A small active fraction of neutral $\alpha$-glucosidase that bound to the column (Fig. 6B) was not true activity of the enzyme, since it disappeared on heating at $60^{\circ} \mathrm{C}$ for $5 \mathrm{~min}$, conditions in which acid $\alpha$-glucosidase was stable, as observed in Fig. 2. 


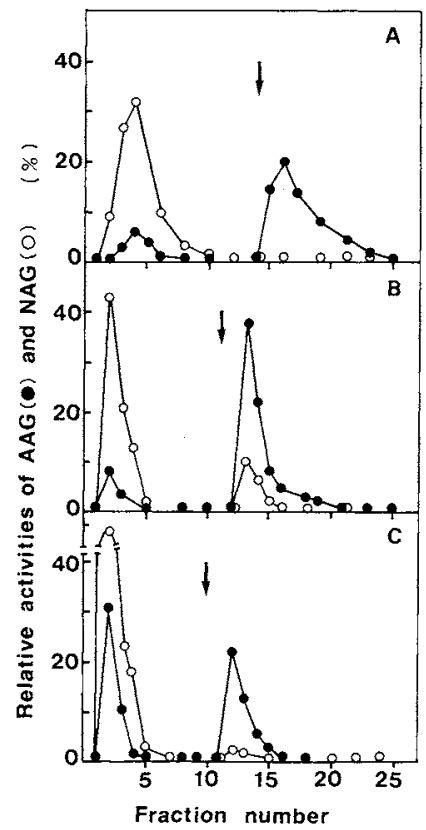

Fig. 6. Con A-Sepharose Column Chromatograms of Banana $\alpha$-Glucosidases.

The active fraction was obtained by $20 \%$ PEG precipitation from the crude extracts, dissolved in $50 \mathrm{~mm}$ phosphate buffer ( $\mathrm{pH}$ 6.5) containing $0.1 \mathrm{M} \mathrm{NaCl}$, then put on a Con A-Sepharose column. After the column was washed with the same buffer, the same buffer containing $15 \mathrm{~mm}$ methyl $\alpha$-D-glucopyranoside was put on, as indicated by an arrow. The ordinate scale shows the relative activity ( $\%$ of total) of the enzyme measured at $\mathrm{pH} 4.5$ (acid $\alpha$-glucosidase, AAG) or pH 6.5 (neutral $\alpha$-glucosidase, NAG). The samples, (A), (B), and (C), were the same to those described in the legend of Fig. 5.

\section{Discussion}

Garcia and Lajolo ${ }^{9)}$ observed a large increase in activity of banana neutral $\alpha$-glucosidase at the climacteric phase when bananas was ripened naturally, but they did not measure acid $\alpha$-glucosidase activity. Further these authors reported multiple forms of the enzyme by activity staining that gave no differences in electrophoretic patterns through ripening of bananas. This method, or isoelectric focusing on polyacrylamide gel, has been widely used for investigating protein polymorphism for its high resolution, but it is less quantitative than analysis by chromatofocusing. ${ }^{14)}$ This study using chromatofocusing showed clearly that the apparent pIs of banana $\alpha$-glucosidases varied during ripening, in contrast to the result of Garcia and Lajolo. ${ }^{9)}$ At present, however, it is unknown whether heterogeneity of $\alpha$-glucosidases observed in this study is derived from newly-synthesized isozymes from different genes or post-translational modifications of the preexisted enzymes. It has been shown that acid phosphatase, which is the enzyme that increases most in activity in the course of ripening of bananas, ${ }^{6,7,15-17)}$ was heterogeneous due to a sequential de novo synthesis of isozymes. ${ }^{16)}$

Little attention has been paid to $\alpha$ glucosidase as a glycoprotein in the research on multiple enzyme forms in plant tissues including banana pulp. ${ }^{19)}$ As shown in Fig. 6, a large amount of acid $\alpha$-glucosidase was found to be a glycoprotein that showed affinity for the Con A column. The decrease in the amount of the glycoprotein in a ripe yellow banana suggests that deglycosylation of protein might occur during ripening.

This study provides preliminary information not only on investigating the mechanism of appearance of multiple forms of $\alpha$-glucosidase or isozymes but also on the strategy for purification of $\alpha$-glucosidases from bananas at various stages of ripening.

\section{References}

1) R. E. Young, S. Salminen and P. Sornsrivichai, Coll. Int. Centre National Recherche Scientifique, No. 238, p. 271 (1974).

2) J. Marriott, CRC Crit. Rev. Food Sci. Nutr., 13, 41 (1980).

3) M. Steup, in "The Biochemistry of Plants," Vol. 14, ed. by J. Preiss, Academic Press, San Diego, 1988, pp. 255-296.

4) E. Beck and P. Ziegler, Annu. Rev. Plant Physiol. Plant Mol. Biol., 40, 95 (1989).

5) C. M. Duffus and J. H. Duffus, in "Carbohydrate Metabolism in Plants," Longman, London and New York, 1984.

6) A. B. Chitarra and F. M. Lajolo, J. Am. Soc. Hort. Sci., 106, 579 (1981).

7) B. B. Desai and P. B. Deshpande, Sci. Hort., 9, 147 (1978).

8) W. W. Mao and J. E. Kinsella, J. Food Sci., 46, 1400 (1981). 
9) E. Garcia and F. M. Lajolo, J. Food Sci., 53, 1181 (1988).

10) J. A. G. Arêas, F. M. Lajolo, J. Food Biochem., 5, 19 (1981).

11) S. Kitazato, Y. Konishi and N. Nakatani, Abstracts of Papers, the Annual Meeting of the Japanese Society of Starch Science, Kagoshima, August, 1990 , p. 21

12) M. Baijal, S. Singh, R. N. Shukla and G. G. Sanwal, Phytochemistry, 11, 929 (1972).

13) Y. Konishi, Y. Okawa, S. Hosokawa, K. Fujimori and H. Fuwa, J. Biochem., 107, 197 (1990).
14) A. W. MacGregor, B. A. Marchylo and J. E. Kruger, Cereal Chem., 65, 326 (1988).

15) H. Hyodo, K. Tanaka, T. Suzuki, M. Mizukoshi and Y. Tasaka, J. Jpn. Soc. Hort. Sci., 50, 379 (1981).

16) P. DeLeo and J. A. Sacher, Plant Physiol., 46, 208 (1970).

17) J. A. Sacher, Annu. Rev. Plant Physiol, 24, 197 (1973).

18) A. K. Kanellis, T. Solomos and A. K. Mottoo, Plant Physiol., 90, 251 (1989).

19) P. M. Dey and E. D. Campillo, Adv. Enzymol., 56, 141 (1984). 